\title{
Usefulness of rabbit antibodies obtained by two methods in detection of Clavibacter michiganensis subsp. sepedonicus by application of DAS-ELISA test
}

\author{
Przydatność przeciwciał króliczych \\ uzyskiwanych dwiema metodami do wykrywania \\ Clavibacter michiganensis subsp. sepedonicus testem DAS-ELISA
}

\author{
Wioleta Stochła, Agnieszka Przewodowska, Włodzimierz Przewodowski*
}

\begin{abstract}
Summary
Clavibacter michiganensis subsp. sepedonicus $(\mathrm{Cms})$ bacterium is responsible for ring rot of potato, one of the most dangerous disease that affects potato plants and tubers. The best method to limit the disease propagation is quick and sensitive diagnostic of $\mathrm{Cms}$ bacteria. The deciding factor for the effectiveness of the immunologic tests is the quality of antibodies that detect the pathogen. In order to examine the influence of isolation of the antibodies aimed at entire bacterium cells ( $\mathrm{Cms}$ ) on their quality, two different methods of ion-exchange chromatography allowing isolation of IgG from rabbit blood serum were assessed. Separations were performed in columns filled with DEAE cellulose (diethylaminoethyl cellulose) and thiophilic Sepharose beds respectively. The stage that preceded chromatographic separations in both methods comprised an initial purification by precipitation of proteins from the serum in presence of salt solution. Using both matrices a preparative isolation of antibodies and removal of other impurities were achieved. The applied methods were compared in terms of quality of the antibodies obtained as well as time and difficulty of their accomplishment. Sensitivity of the antibodies to detect $\mathrm{Cms}$ bacteria was examined by application of DAS-ELISA assay (doubleantibody sandwich enzyme linked immunosorbent assay).
\end{abstract}

Key words: antibodies; immunoassays; ion exchange chromatography; potato ring rot bacteria

\section{Streszczenie}

Bakteria Clavibacter michiganensis subsp. sepedonicus (Cms) jest sprawcą bakteriozy pierścieniowej ziemniaka, jednej z najgroźniejszych chorób tej rośliny. Najlepszym sposobem ograniczenia rozprzestrzeniania się tej choroby jest szybka i czuła diagnostyka bakterii $\mathrm{Cms}$. W testach immunologicznych czynnikiem decydującym o skuteczności prowadzonej diagnostyki jest jakość przeciwciał wykrywających danego patogena. W celu zbadania wpływu sposobu izolacji przeciwciał skierowanych na całe komórki bakterii (Cms), na ich jakość, oceniano dwie różne metody chromatografii jonowymiennej pozwalające na izolację immunoglobuliny $\mathrm{G}$ (IgG) z surowicy krwi króliczej. Rozdziały prowadzono w kolumnach wypełnionych odpowiednio złożem z DEAE-celulozy (diethylaminoethyl cellulose dietyloaminoetylo-celulozy) oraz złożem z sefarozy tiofilnej. Etapem poprzedzającym rozdziały chromatograficzne w obu metodach było oczyszczanie wstępne przez strącanie białek z surowicy w obecności stężonego roztworu soli. Przy wykorzystaniu obu matryc uzyskano preparatywną izolację przeciwciał oraz usunięcie pozostałych zanieczyszczeń. Stosowane metody porównywano pod kątem jakości otrzymywanych przeciwciał oraz czasu i trudności wykonania. Czułość uzyskanych przeciwciał w wykrywaniu bakterii Cms oceniano testem DAS-ELISA (double-antibody sandwich enzyme linked immunosorbent assay - test immunoenzymatyczny z podwójnym wiązaniem przeciwciał).

Słowa kluczowe: przeciwciała; testy immunologiczne; chromatografia jonowymienna; bakterioza pierścieniowa ziemniaka

Instytut Hodowli i Aklimatyzacji Roślin - Państwowy Instytut Badawczy

Zakład Nasiennictwa i Ochrony Ziemniaka

Bonin 3, 76-009 Bonin

*corresponding author: w. przewodowski@ihar.edu.pl 


\section{Wstęp / Introduction}

Bakterioza pierścieniowa ziemniaka jest jedną z groźniejszych chorób tej rośliny powodowaną przez bakterię Clavibacter michiganensis subsp. sepedonicus (Cms). Szczególnym problemem w zwalczaniu tego patogena jest jego utrudniona diagnostyka. Ze względu na zróżnicowaną mukoidalność poszczególnych szczepów Cms, występowanie choroby w postaci bezobjawowej oraz braku pożywek selektywnych dla tej bakterii, jednoznaczna diagnoza wymaga przeprowadzenia kilku testów jednocześnie (EPPO 2006). Ciągle poszukuje się nowych testów i rozwiązań pozwalających na usprawnienie diagnostyki zarówno metodami molekularnymi, jak i serologicznymi. Czułość i specyficzność testów serologicznych jest ściśle związana z jakością przeciwciał użytych podezas wykonywania badania. Przeciwciała jako cząsteczki receptorowe o wysokiej zdolności wiązania innych cząsteczek - antygenów, są często wykorzystywane w metodach diagnostycznych do wykrywania bakteryjnych i wirusowych patogenów roślin. Do takich metod można zaliczyć m.in.: immunoenzymatyczny test ELISA (enzyme linked immunosorbent assay - test immunoenzymatyczny) do wykrywania wirusów i bakterii (De Boer i wsp. 2005), test pośredniej immunofluorescencji - IF (indirect fluorescent antibody test) (Slack i wsp. 1979; De Boer i Copeman 1980), fluorescencyjną hybrydyzację In situ - FISH (fluorescent in situ hybridization) (Van Beuningen i wsp. 1995), a także opracowane w Zakładzie Nasiennictwa i Ochrony Ziemniaka w Boninie testy immunofiltracyjne oraz filtracyjne typu Flow-Through do szybkiej i specyficznej identyfikacji czystych szczepów bakterii Cms powodujących bakteriozę pierścieniową ziemniaka (Przewodowski 2000; Przewodowski i Barnyk 2009). Jednymi z najczęściej stosowanych przeciwciał $\mathrm{w}$ testach immunologicznych są poliklonalne królicze immunoglobuliny $\mathrm{G}$ (IgG). Jakość IgG, czyli w głównej mierze ich miano i czystość, zależy nie tylko od jakości wyjściowych surowic, lecz również od sposobu izolacji przeciwciał (Barnyk i wsp. 2008). Znajomość właściwości oczyszczanego białka oraz samych zanieczyszczeń, które należy usunąć, są kluczowe dla prawidłowego oczyszczania przeciwciał z materiału biologicznego, otrzymania przeciwciał o niezmienionej strukturze $\mathrm{i}$ wymaganej aktywności biologicznej.

W badaniach dokonano oceny wpływu sposobu izolacji przeciwciał IgG anty-Cms z surowicy króliczej na jakość uzyskanych przeciwciał wpływającą na czułość i specyficzność testów immunoenzymatycznych w diagnostyce tego groźnego patogena.

\section{Materiały i metody / Materials and methods}

\section{Szczepy bakteryjne}

Do badań wykorzystano trzy zróżnicowane mukoidalnie szczepy bakterii $C$. michiganensis ssp. sepedonicus, z których pierwszy niemukoidalny (BPR IOR 527) pochodził z Banku Patogenów Roślin Instytutu Ochrony Roślin Państwowego Instytutu Badawczego w Poznaniu, natomiast dwa pozostałe szczepy średnio- i silniemukoidalny (odpowiednio PD 221 i PD 406), pozyskano z holenderskiej kolekcji kultur patogenów roślin Research Institute for Plant
Protection w Wageningen. Do badań wykorzystywano komórki bakteryjne pochodzące z 48-godzinnych hodowli namnażanych na podłożu wzrostowym YGM (yeast extract mineral salts medium - pożywka mineralna $\mathrm{z}$ wyciągiem drożdżowym) (OEPP/EPPO 2006).

\section{Izolacja przeciwcial z surowicy króliczej}

Jako wyjściowy materiał badawczy wykorzystano surowicę krwi króliczej zawierającą przeciwciała skierowane na kwarantannowe bakterie Cms. Przed naniesieniem na kolumnę chromatograficzną, preparaty surowic wstępnie oczyszczano i wytrącano badane $\operatorname{IgG}$ z surowicy krwi przez precypitację w 50\% roztworze siarczanu amonu (Hebert i wsp. 1973). W następnym etapie uzyskane białka poddawano rozdziałowi techniką chromatografii jonowymiennej stosując dwa rodzaje złóż, odpowiednio złoże z DEAE (dwuetyloaminoetylowa celuloza) (Yang i Harrison 1996) oraz złoże $z$ sefarozą tiofilną (Barnyk i wsp. 2008). W pierwszym przypadku na kolumnę zrównoważoną buforem fosforanowym $0,5 \times \mathrm{PBS} \mathrm{z} \mathrm{NaN}_{3}, \mathrm{pH}=7,4$ nakładano wstępnie oczyszczone białka zawieszone $\mathrm{w}$ takim samym buforze. Po rozdziale chromatograficznym, na wypływie kolumny jako pierwsze zbierano frakcje zawierające oczyszczone $\mathrm{IgG}$, a następnie eluowano ze złoża białka inne niż IgG stosując bufor fosforanowy 0,5 $\times$ PBS zawierający $1 \mathrm{M} \mathrm{NaCl}$ (rys. 1a).

$\mathrm{W}$ drugiej z ocenianych metod, przeciwciała nanoszono w buforze o wysokim stężeniu soli $\left(0,5 \quad \mathrm{M} \mathrm{K}_{2} \mathrm{SO}_{4}\right.$ w $10 \mathrm{mM} \mathrm{NaPi}$, pH = 7,4) na kolumnę wypełnioną sefarozą tiofilną (Barnyk i wsp. 2008). W takich warunkach następowało wiązanie się przeciwciał do złoża, natomiast białka inne niż IgG wypływały $\mathrm{z}$ kolumny. Elucję przeciwciał związanych ze złożem prowadzono obniżając siłę jonową buforu stosując $10 \mathrm{mM}$ bufor $\mathrm{NaPi}$ (rys. 1b).

\section{Chromatografia}

Rozdziały chromatograficzne prowadzono w kolumnach wypełnionych złożami z DEAE celulozą oraz sefarozą tiofilną. Przed umieszczeniem $\mathrm{w}$ kolumnie, złoże z celulozą DEAE, aktywowano przez moczenie przez noc w $100 \mathrm{ml} \mathrm{H}_{2} \mathrm{O} 5 \mathrm{~g}$ wyjściowej celulozy [Cellulose Ion Exchanger typ DEAE $(0,74)]$ i następne kilkukrotne przepłukanie w $0,5 \mathrm{M}$ roztworach $\mathrm{NaOH}$ i $\mathrm{HCl}$. Zmodyfikowaną sefarozę tiofilną 6B Sepharose (Pharmacia) aktywowano, podobnie jak w publikacji Barnyk i wsp. (2008) stosując kolejno roztwory: di-winyl-sulfonu w $0,5 \mathrm{M}$ węglanie sodu, $0,1 \mathrm{M}$ węglan sodu $(\mathrm{pH}=9)$ oraz merkaptoetanol. W końcowym etapie złoże buforowano przemywając $0,2 \mathrm{M}$ buforem TRiS/HCl.

\section{Określanie stężenia białka i jego czystości}

Stężenie przeciwciał $\operatorname{IgG} \mathrm{w}$ badanych próbach oznaczano spektrofotometrycznie mierząc absorbancję każdej z frakcji przy 3 długościach fal: 235, 250 i $280 \mathrm{~nm}$, a następnie wyliczając z zależności (Whitaker i Granum 1980):

$$
\mathrm{C} \text { IgG }[\mathrm{mg} / \mathrm{ml}]=\mathrm{A}_{280} / 1,4
$$

C IgG - stężenie $\operatorname{IgG}$,

$\mathrm{A}_{280}$ - absorbancja przy $280 \mathrm{~nm}$,

1,4 - wartość absorbancji $\mathrm{A}_{280}$ dla $1 \mathrm{mg} \mathrm{IgG/ml}$. 
Czystość otrzymanych przeciwciał określano spektrofotometrycznie określając stosunek absorbancji 280/250 nm, który dla wysoko oczyszczonych IgG króliczych wynosi 2,5-2,7 (Barnyk i wsp. 2008) oraz dokonując rozdziału elektroforetycznego białek w żelu poliakrylamidowym w warunkach redukujących.

\section{Określenie miana przeciwciał}

Miano, czułość oraz specyficzność wytworzonych przeciwciał oceniano za pomocą testu DAS-ELISA (double-antibody sandwich enzyme linked immunosorbent assay - test immunoenzymatyczny $\mathrm{z}$ podwójnym wiązaniem przeciwciał) w mikropłytkach polistyrenowych firmy Nunc, stosując jako bufor powlekający A (50 mM bufor węglanowy, $\mathrm{pH}=9,6)$, bufor do płukania B (10 mM PBS, $\mathrm{pH}=7,4 \mathrm{z} 0,05 \%$ Tween 20), bufor koniugatowy C (10 mM PBS, 0,05\% Tween 20, 2\% PVP, 1\% żelatyna, $\left.1 \mathrm{mM} \mathrm{MgCl} 2 \times 6 \mathrm{H}_{2} \mathrm{O}\right)$ oraz bufor substratowy D (1 M dwuetanoloamina, $1 \mathrm{mM} \mathrm{MgCl} \mathrm{Mg}_{2} \mathrm{H}_{2} \mathrm{O}, 0,02 \mathrm{M} \mathrm{NaN}_{3}, \mathrm{pH}$ $=9,8) \mathrm{z}$ pNPP $(1 \mathrm{mg} / \mathrm{ml})$ - substratem dla alkalicznej fosfatazy. Jako próbę odnośną stosowano bufor bez bakterii Cms. Absorbancję mierzono przy $\lambda=405 \mathrm{~nm}$ po 1, 2 i 4 godzinach inkubacji. Za wynik pozytywny przyjmowano absorbancję przekraczającą co najmniej dwukrotną wartość absorbancji uzyskanej dla buforu bez bakterii Cms. Jeżeli na prezentowanych wykresach nie zaznaczono poziomu kontroli negatywnej, wówczas przedstawiono wyniki uzyskane po jej odjęciu.

\section{Wyniki i dyskusja / Results and discussion}

W przypadku kolumny wypełnionej złożem z celulozą DEAE, przeciwciała, które mają słabsze niż pozostałe białka surowicy powinowactwo do złoża, wypływały w pierwszym piku, w kolejnym piku wypływały niezwiązane białka. Odwrotny profil wypływu zaobserwowano dla kolumny wypełnionej sefarozą tiofilną. W drugim przypadku przeciwciała silnie wiązały się do złoża tiofilnego w obecności wysokiego stężenia soli, pozwalając jednocześnie na usunięcie innych białek oraz zanieczyszczeń znajdujących się w oczyszczanym preparacie $\mathrm{z}$ surowicy krwi. Wskutek tego w chromatografi tiofilnej jako pierwsze wypływają białka niezwiązane do kolumny, natomiast związane przeciwciała wypływają w dalszej kolejności po zastosowaniu buforu bez soli, pozwalającego na obniżenie siły wiązania IgG do złoża.

Stopień wiązania przeciwciał do kolumny i elucję związanych cząstek z obu kolumn oceniano przez pomiar absorbancji przy długości fali 235, 250 i $280 \mathrm{~nm}$ w wypływających frakcjach. Wyniki dla frakcji zawierających IgG wypływających z kolumny wypełnionej celulozą DEAE przedstawiono $\mathrm{w}$ tabeli 1., natomiast ze złoża

Tabela 1. Ilość przeciwciał IgG we frakcjach uzyskanych z DEAE (dwuetyloaminoetylowej) celulozy

Table 1. The amount of IgG antibody in the fractions obtained from the DEAE (diethylaminoethyl) cellulose

\begin{tabular}{c|c|c|c|c|c|c}
\hline $\begin{array}{c}\text { Frakcja } \\
\text { Fraction }\end{array}$ & $\begin{array}{c}\text { Objętość } \\
\text { Volume } \\
{[\mathrm{ml}]}\end{array}$ & A 235 nm & A 250 nm & A 280 nm & $\begin{array}{c}\text { IgG } \\
{[\mathrm{mg} / \mathrm{ml}]}\end{array}$ & $\begin{array}{c}\text { Czystość } \\
\text { Purity } \\
\left(\mathrm{A}_{280 / 250}\right)\end{array}$ \\
\hline 1 & 1,6 & 0,5031 & 0,0733 & 0,1821 & 0,130 & 2,5 \\
\hline 2 & 1,6 & 0,8252 & 0,1209 & 0,3169 & 0,226 & 2,6 \\
\hline 3 & 1,6 & 1,0411 & 0,1577 & 0,4168 & 0,298 & 2,6 \\
\hline 4 & 1,6 & 1,0631 & 0,1589 & 0,4347 & 0,311 & 2,7 \\
\hline 5 & 1,6 & 0,7572 & 0,1061 & 0,3122 & 0,223 & 2,9 \\
\hline
\end{tabular}

A $235 \mathrm{~nm}$, A $250 \mathrm{~nm}$, A $280 \mathrm{~nm}$ - absorbancja przy długości fali $235 \mathrm{~nm}, 250 \mathrm{~nm}, 280 \mathrm{~nm}$ - the absorbance at wave length of $235 \mathrm{~nm}, 250 \mathrm{~nm}, 280 \mathrm{~nm}$ IgG - immunoglobuliny $\mathrm{G}$ - immonoglobulins $\mathrm{G}$

Tabela 2. Ilość przeciwciał IgG we frakcjach uzyskanych ze złoża z sefarozy tiofilnej

Table 2. The amount of IgG antibody in the fractions obtained from thiophilic sepharose

\begin{tabular}{c|c|c|c|c|c|c}
\hline $\begin{array}{c}\text { Frakcja } \\
\text { Fraction }\end{array}$ & $\begin{array}{c}\text { Objętość } \\
\text { Volume } \\
{[\mathrm{ml}]}\end{array}$ & A $235 \mathrm{~nm}$ & A $250 \mathrm{~nm}$ & A $280 \mathrm{~nm}$ & $\begin{array}{c}\text { IgG } \\
{[\mathrm{mg} / \mathrm{ml}]}\end{array}$ & $\begin{array}{c}\text { Czystość } \\
\text { Purity } \\
\left(\mathrm{A}_{280 / 250}\right)\end{array}$ \\
\hline 1 & 0,6 & 2,3874 & 0,5670 & 0,9727 & 0,695 & 1,7 \\
\hline 2 & 0,6 & 2,6398 & 0,4698 & 1,0338 & 0,738 & 2,2 \\
\hline 3 & 0,6 & 1,9042 & 0,2916 & 0,6859 & 0,490 & 2,4 \\
\hline 4 & 0,6 & 1,4505 & 0,2069 & 0,5032 & 0,359 & 2,4 \\
\hline 5 & 0,6 & 1,1721 & 0,1625 & 0,3951 & 0,282 & 2,4 \\
\hline 6 & 0,6 & 0,9034 & 0,1214 & 0,2980 & 0,213 & 2,5 \\
\hline 7 & 0,6 & 0,7102 & 0,0924 & 0,2296 & 0,164 & \\
\hline
\end{tabular}

A $235 \mathrm{~nm}$, A $250 \mathrm{~nm}$, A $280 \mathrm{~nm}$ - absorbancja przy długości fali $235 \mathrm{~nm}, 250 \mathrm{~nm}, 280 \mathrm{~nm}$ - the absorbance at wave length of $235 \mathrm{~nm}, 250 \mathrm{~nm}, 280 \mathrm{~nm}$ $\mathrm{IgG}$ - immunoglobuliny $\mathrm{G}$ - immonoglobulins $\mathrm{G}$ 
Tabela 3. Miano przeciwciał oczyszczanych metodą chromatografii tiofilnej i na DEAE (dwuetyloaminoetylowej) celulozie. Oceny dokonano metodą DAS-ELISA jako antygen stosując średniomukoidalny szczep bakterii Cms. Średnia i odchylenie standardowe obliczono dla trzech powtórzeń

Table 3. The antibody titer purified by thiophilic chromatography and DEAE (diethylaminoethyl) cellulose. The assessment was made by DAS-ELISA using as antigen mucoid, intermediate strain Clavibacter michiganensis subsp. sepedonicus. The mean and standard deviation were calculated for three replicates

\begin{tabular}{l|c|c|c|c}
\hline \multirow{2}{*}{$\begin{array}{c}\text { Rozcieńczenie } \\
\text { Dilution }\end{array}$} & \multicolumn{2}{c|}{$\begin{array}{c}\text { IgG oczyszczane na złożu tiofilnym } \\
\text { IgG purified on thiophilic sepharose }\end{array}$} & \multicolumn{2}{c}{$\begin{array}{c}\text { IgG oczyszczane na DEAE celulozie } \\
\text { IgG purified on DEAE cellulose }\end{array}$} \\
\cline { 2 - 5 } & $\mathrm{A}_{405}$ & $\mathrm{SD}$ & $\mathrm{A}_{405}$ & SD \\
\hline $1000000 \mathrm{x}$ & 0,027 & 0,005 & 0,015 & 0,004 \\
\hline $100000 \mathrm{x}$ & 0,019 & 0,004 & 0,027 & 0,007 \\
\hline $10000 \mathrm{x}$ & 0,825 & 0,010 & 0,698 & 0,009 \\
\hline $1000 \mathrm{x}$ & 1,531 & 0,015 & 1,463 & 0,015 \\
\hline $100 \mathrm{x}$ & 1,630 & 0,016 & 1,721 & 0,017 \\
\hline $10 \mathrm{x}$ & 1,649 & 0,016 & 1,642 & 0,016 \\
\hline
\end{tabular}

$\mathrm{A}_{405}$ - absorbancja w $405 \mathrm{~nm}$ - absorbance at $405 \mathrm{~nm}$

$\mathrm{SD}$ - odchylenie standardowe - standard deviation

IgG - immunoglobuliny $\mathrm{G}$ - immunoglobulins

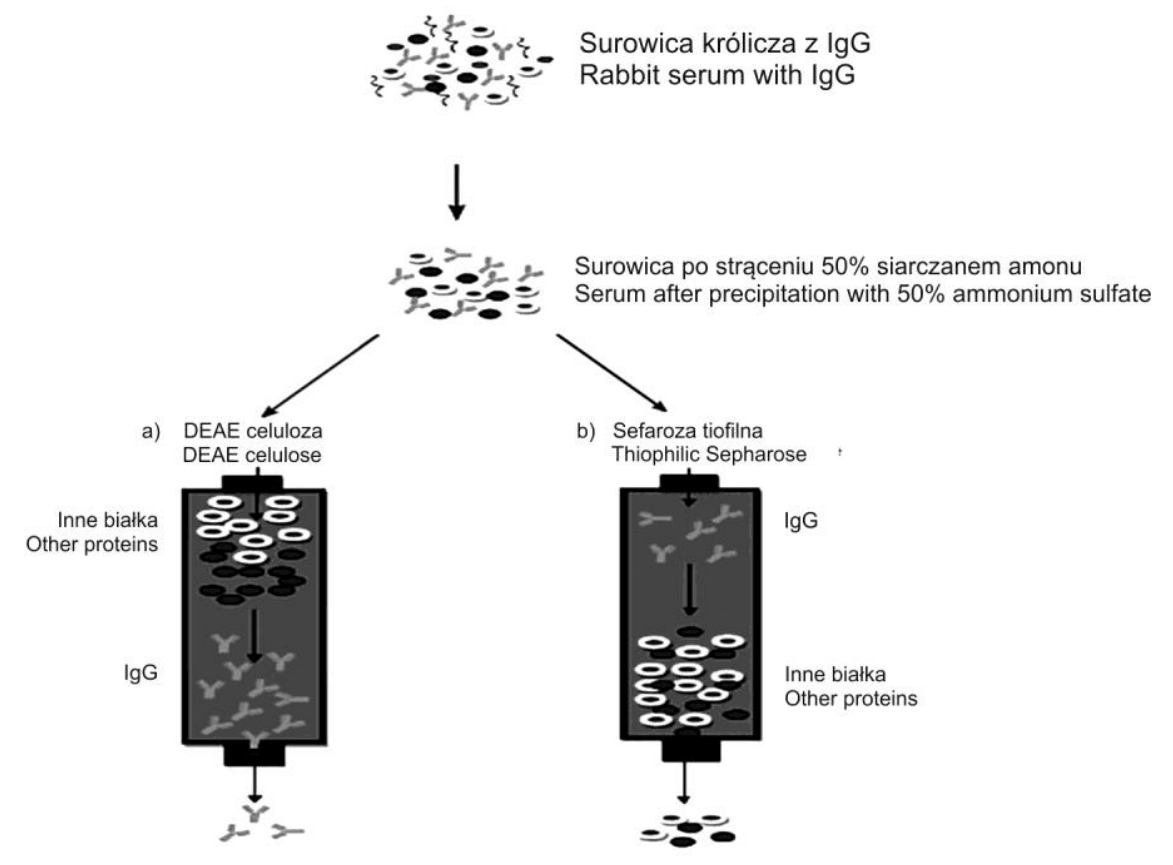

Rys. 1. Schemat oczyszczania IgG na złożu z: a) celulozą DEAE (dwuetyloaminoetylową), b) tiofilną sefarozą (źródło: własne)

Fig. 1. IgG purification system on a bed of: a) DEAE (diethylaminoethyl) cellulose, b) thiophilic Sepharose (source: own)

z sefarozą tiofilną w tabeli 2. Przy zastosowaniu takiej samej próby wyjściowej dla obu kolumn chromatograficznych, w obu metodach uzyskano podobną końcową ilość przeciwciał, przy czym koncentracja uzyskanych IgG metodą $\mathrm{z}$ użyciem złoża tiofilnego była dwukrotnie wyższa. W przypadku celulozy DEAE otrzymano 1,9 mg IgG w $8 \mathrm{ml} \mathrm{w}$ eluacie, natomiast zastosowanie kolumny wypełnionej sefarozą tiofilną pozwoliło uzyskać $1,8 \mathrm{mg}$ przeciwciał, ale w dwukrotnie mniejszej objętości - 4,2 ml. Otrzymane drugim sposobem przeciwciała wypłynęły bardziej skoncentrowane, co jest zaletą tej techniki.

Analiza rozdziału elektroforetycznego w żelu poliakrylamidowym badanych frakcji wykazała, że oba sposoby izolacji pozwalają uzyskać dobrze oczyszczone przeciwciała $\mathrm{z}$ małą domieszką białek niespecyficznych. Nie- znacznie lepszą efektywność oczyszczania wykazała metoda z wykorzystaniem celulozy DEAE (rys. 2).

Przeciwciała oczyszczane na celulozie DEAE bezpośrednio na wypływie kolumny zawieszano w buforze fosforanowym $0,5 \times$ PBS imitującym naturalne środowisko przeciwciał. Natomiast przeciwciała otrzymane $z$ elucji ze złoża $\mathrm{z}$ tiofilną sefarozą wypływały $\mathrm{w}$ buforze zawierającym pozostałości soli z kolumny, co przy dłuższym przechowywaniu mogło niekorzystnie wpływać na ich aktywność biologiczną. Dlatego w drugim przypadku niezbędne było zastosowanie dodatkowego etapu dializy pozwalającego na usunięcie pozostałości soli. Ujemnym skutkiem tego etapu jest przedłużenie czasu oczyszczania przeciwciał. 


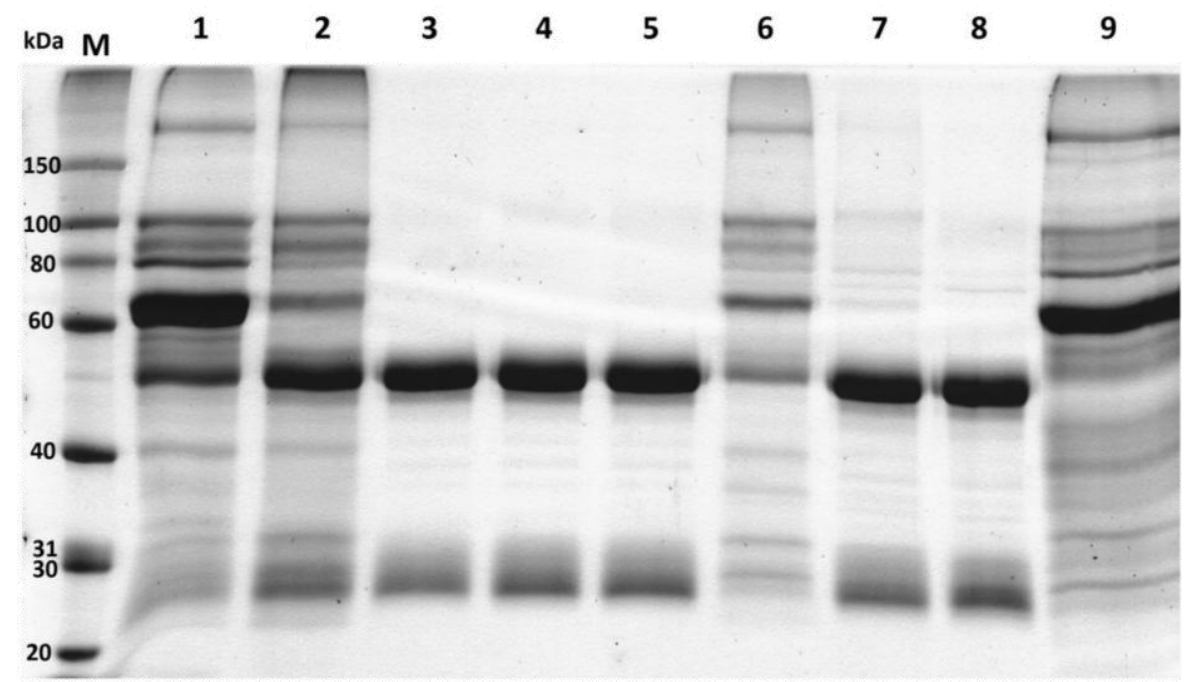

Rys. 2. Profil elektroforetyczny badanych IgG w żelu poliakrylamidowym w warunkach redukujących: M - wzorzec masy cząsteczkowej białka, Roti-Mark 10-150 Plus, Carl Roth GmbH + Co. KG; 1) surowica królicza przed oczyszczaniem $(50 \times$ rozcieńczona); 2) surowica po strąceniu 50\% roztworem siarczanu amonu; 3), 4), 5) IgG po oczyszczaniu na celulozie DEAE $\left.\left(\mathrm{A}_{280}=0,5\right) ; 6\right)$ białka surowicy związane do DEAE celulozy; 7), 8) IgG po oczyszczaniu na złożu: sefarozie tiofilnej $\left.\left(\mathrm{A}_{280}=0,5\right) ; 9\right)$ białka niezwiązane z tiofilną sefarozą

Fig. 2. Electrophoretic profile of $\operatorname{IgG}$ in a polyacrylamide gel under reducing conditions: $\mathrm{M}$ - molecular weight standard, 1) rabbit serum before treatment $(50 \times$ diluted); 2) serum after precipitation of $50 \%$ ammonium sulfate; 3), 4), 5) IgG after purification on DEAE cellulose $\left(\mathrm{A}_{280}=0.5\right)$; 6) serum proteins bound to the DEAE cellulose; 7), 8) IgG after purification on thiophilic Sepharose $\left(\mathrm{A}_{280}=0.5\right)$; 9) protein unbound to thiophilic Sepharose

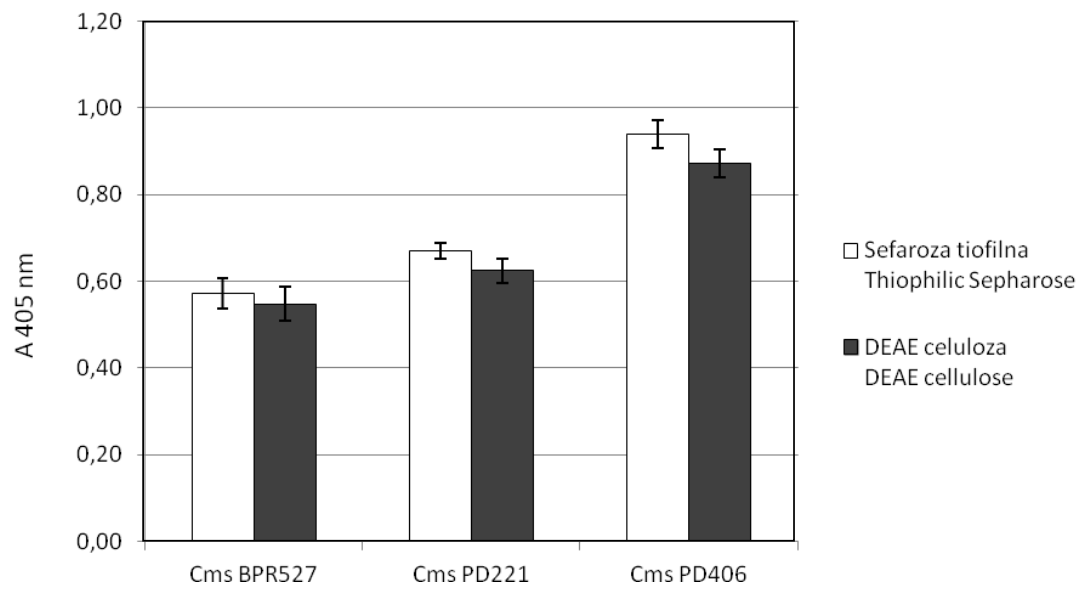

Rys. 3. Czułość testu DAS-ELISA wykonanego przy udziale IgG oczyszczanych metodą chromatografii tiofilnej oraz na DEAE celulozie

Fig. 3. The sensitivity of the DAS-ELISA assay with the IgG purified by thiophilic chromatography and on DEAE cellulose

Miano przeciwciał oczyszczanych obiema metodami oceniano metodą DAS-ELISA stosując, jako antygen średniomukoidalny szczep bakterii Cms PD 221. Niezależnie od zastosowanej metody miano uzyskanych przeciwciał wyniosło 10000 razy (tab. 3) i takie rozcieńczenie stosowano w teście DAS-ELISA badając trzy zróżnicowane mukoidalnie szczepy bakterii Cms.

Dla wszystkich badanych szczepów, niezależnie od stopnia ich mukoidalności otrzymano pozytywne wyniki w teście DAS-ELISA (rys. 3). Największą czułość testu otrzymano dla szczepu Cms PD 406 charakteryzującego się wysoką zawartością śluzów. Najniższe wartości pomiaru absorbancji otrzymano dla szczepu niskomuko- idalnego BPR 527. Oba rodzaje przeciwciał wykazały porównywalną czułość dla poszczególnych szczepów Cms.

\section{Wnioski / Conclusions}

1. Wykazano przydatność i wysoką skuteczność obu badanych metod w oczyszczaniu IgG z surowicy krwi króliczej.

2. Czystość otrzymanych przeciwciał IgG była wyższa $\mathrm{w}$ metodzie $\mathrm{z}$ zastosowaniem dodatnio naładowanego złoża z celulozą DEAE. Technika ta nie wymaga dializowania preparatu po zakończeniu chromatografii, 
ale oczyszczone przeciwciała uzyskuje się w niskiej koncentracji.

3. Zastosowanie chromatografii tiofilnej pozwala uzyskać przeciwciała $\mathrm{w}$ skoncentrowanym preparacie, ale po zakończeniu izolacji konieczny jest etap dializy, co zwiększa czasochłonność samego procesu oczyszczania.

4. Czułość obu przeciwciał jest porównywalna niezależnie od mukoidalności badanych szczepów ani sposobu, w jaki zostały otrzymane.

\section{Literatura / References}

Barnyk A., Lewosz J., Treder K., Przewodowski W., Pilecki T. 2008. Zastosowanie chromatografii tiofilnej do izolacji przeciwciał poliklonalnych z surowicy krwi królików. Biuletyn Instytutu Hodowli i Aklimatyzacji Roślin 248: 87-95.

De Boer S.H., Copeman R.J. 1980. Bacterial ring rot testing with the indirect fluorescent antibody staining procedure. American Journal of Potato Research 57: 457-465.

De Boer S.H., Charkowski A.O., Zink R.T., Martinez-Soriano J.P., Flores-Olivas A. 2005. Procedure for detection and identification of Clavibcter michiganensis subsp. sepedonicus (Spieckermann and Kotthoff) Davis, Gillaspie, Vidaver and Harris, in potato (Solanum tuberosum L.) tubers. Revista Mexicana de Fitopatologia 23: 329-334.

Hebert G.A., Pelham P.L., Pittman B. 1973. Determination of the optimal ammonium sulfate concentration for the fractionation of rabbit, sheep, horse and goat antisera. Journal of Applied Microbiology 25: 26-36.

OEPP/EPPO 2006. Clavibacter michiganensis subsp. sepedonicus. Bulletin OEPP/EPPO Bulletin 36: 99-109.

Przewodowski W., Barnyk A. 2009. Szybki test do identyfikacji bakterii Clavibacter michiganensis ssp. sepedonicus. [Rapid test for identification of Clavibacter michiganensis ssp. sepedonicus]. Progress in Plant Protection/Postępy w Ochronie Roślin 49 (2): 696-700.

Przewodowski W. 2009. Szybki immunologiczny test do identyfikacji bakterii Clavibacter michiganensis ssp. sepedonicus. Konferencja naukowo-szkoleniowa „Nasiennictwo i ochrona ziemniaka”. IHAR, ZNiOZ Bonin. Darłówko, 21-22.05.2009, 78 ss.

Slack S.A., Sanford H.A., Manzer F.E. 1979. The latex agglutination test as rapid serological assay for Corynabacterium sepedonicum. American Journal of Potato Research 56: 441-446.

Van Beuningen A.R., Derks H., Janse J.D. 1995. Detection and identification of Clavibacter michiganensis subsp. sepedonicus with special attention to fluorescent in situ hybridization (FISH) using a 16S rRNA targeted oligonucleotide probe. Züchtungs Fors chung 1 (2): 266-269.

Whitaker J.R., Granum P.E. 1980. An absolute method for protein determination based on difference in absorbance at 235 and $280 \mathrm{~nm}$. Analytical Biochemistry 109: 156-159.

Yang Y.B., Harrison K. 1996. Influence of column type and chromatographic conditions on the ion-exchange chromatography of immunoglobulins. Journal of Chromatography A 743 (1): 171-180. 